九州大学学術情報リポジトリ

Kyushu University Institutional Repository

\title{
Effects fo Zinc Chemistry on Phytoextraction in Thlaspi caerulescens - Vermiculite System
}

Qian, Xu Dong

Graduate school of Bioresource and Bioenvironmental Science, Kyushu Unviersity

Eguchi, Toshihiko

Biotron Institute, Kyushu University

Yoshida, Satoshi

Biotron Institute, Kyushu University

Chikushi, Jiro

Biotron Institute, Kyushu University

https://doi.org/10.5109/4659

出版情報: 九州大学大学院農学研究院紀要. 50 (2)，pp.459-469，2005-10-01. Faculty of Agriculture, Kyushu University

バージョン :

権利関係 : 


\title{
Effects of Zinc Chemistry on Phytoextraction in Thlaspi caerulescens-Vermiculite System
}

\author{
Xu Dong QIAN', Toshihiko EGUCHI, Satoshi YOSHIDA and Jiro CHIKUSHI*
}

\author{
Biotron Institute, Kyushu University, Hakozaki, 6-10-1, Fukuoka 812-8581, Japan \\ (Received May 2, 2005 and accepted July 26, 2005)
}

\begin{abstract}
Zinc phytoextraction capability of the hyperaccumulator is usually limited by zinc content in the soil. To investigate the effects of different zinc fractions (water-soluble, exchangeable, and non-exchangeable) on phytoextraction of Thlaspi caerulescens from medium of vermiculite, pot experiments were performed for various zinc application treatments $(0 \sim$ $2000 \mathrm{mg} \mathrm{kg}^{-1}$ ). Relationships between zinc quantity accumulated in the plants and zinc content in the medium were investigated. Zinc content accumulated in the shoot of $T$. caerulescens increased and approached a constant value with zinc content in vermiculite. The analysis of zinc balance in vermiculite before and after the growth of $T$. caerulescens revealed that more than $40 \%$ of the zinc content accumulated by $T$. caerulescens is contributed by exchangeable zinc and that a high linear correlation exists between the zinc content in shoot of $T$. caerulescens and the initial exchangeable zinc in vermiculite. Moreover, $17.73-32.94 \%$ of the total zinc uptake by $T$. careulescens was from non-exchangeable fraction. Thus, it was suggested that exchangeable zinc predominantly influenced the zinc uptake by plants and that $T$. caerulescens could contribute to the mobilization of non-labile zinc fraction in vermiculite.
\end{abstract}

\section{INTRODUCTION}

Phytoextraction relies on the hyperaccumulator plants with exceptional metalaccumulating capacities for mobilizing, uptaking, transporting and accumulating the contaminants in harvestable-plant tissues. The phytoextraction has been used to extract heavy metals from contaminated soil recent years (Reeves and Baker, 2000). Zinc (Zn) is an essential micronutrient for plant growth and development but is toxic at high concentrations. A zinc hyperaccumulator plant, Thlaspi caerulescens, has attracted considerable interest because of its remarkable ability to accumulate high contents of metals in its above-ground biomass (Ebbs et al., 1997). The constitutively high expression of zinc transporter genes may play an essential role in zinc hyperaccumulation (Pence et al., 2000; Assunção et al., 2001).

However, the phytoextraction capability of the hyperaccumulator will be limited by zinc content in the soil. The existing type of zinc in soil can be divided into several fractions: (a) in soil solution as free metal ions and soluble metal complexes; (b) adsorbed to inorganic constituent at ion exchange sites; (c) bound to soil organic matter; (d) precipitated such as hydroxides and carbonates; and (e) embedded in crystal lattices of primary minerals (Zhu and Alva, 1993). These different fractions are all in dynamic

\footnotetext{
1 Biotron Institute, Department of Plant Resource, Graduate School of Bioresource and Bioenvironmental Science, Kyushu University

* Corresponding author (E-mail: chiku2@agr.kyushu-u.ac.jp)
} 
equilibrium with each other. Among the zinc fractions, the plant availability differs. The zinc fractions of (a) and (b) mentioned above is available more easily for plant compared with others (Iyengar et al., 1981). Moreover, zinc can be more transferable to the root surface according to convective and dispersion flow, which are controlled by the soil water movement and adsorption/desorption reactions between the bulk soil and the soil solution (Whiting et al., 2003).

Therefore, to successfully manipulate and optimize future phytoextraction technologies, many researches have concerned the chemistry and the plant availability of zinc in soil as well as the mechanism of zinc uptake by T. caerulescens. Brown et al. (1994) concluded that decrease in soil $\mathrm{pH}$ could increase the zinc uptake by $T$. caerulescens. However, McGrath et al. (1997) indicated that T. caerulescens did not cause significant decrease in the $\mathrm{pH}$ of rhizosphere. They also found that the decrease zinc of the mobilizing fraction $\left(\mathrm{NH}_{4} \mathrm{NO}_{3}\right.$-extractable) in soil after $T$. caerulescens growth accounted for less than $10 \%$ of that accumulated in the plant shoot. Similarly, Knight et al. (1997) reported that the decrease of zinc in soil solution accounted for $1 \%$ of the total zinc uptake by $T$. caerulescens, suggesting that Thlaspi caerulescens has the ability to mobilize zinc from less-available pools in the soil. But to date, the process by which $T$. caerulescens mobilizes and takes up zinc has not been identified.

In this study, the distribution of zinc in a T. caerulescens-vermiculite system was investigated to find the relationship between zinc content in medium and zinc uptake by T. caerulescens. The actual amount of the metal available to the plant could differ from that of soil existing in a metal-contaminated site. Vermiculite is a layer-lattice mineral with a mica structure and has characteristic properties such as high cation exchange capacity and high water holding capacity (Wild and Keay, 1964). Therefore, by using vermiculite, zinc content in medium can be analyzed even at relatively high content. This experiment may also be helpful to define the causes of zinc phytotoxicity.

\section{MATERIALS AND METHODS}

\section{Pot culture}

Some seedlings of $T$. caerulescens were planted into pots containing $250 \mathrm{~g} \mathrm{pot}^{-1}$ of vermiculite. Basal fertilizers applied were $100 \mathrm{mg} \mathrm{N} \mathrm{kg}^{-1}$ dry vermiculite as $\mathrm{NH}_{4} \mathrm{NO}_{3}, 80 \mathrm{mg}$ $\mathrm{P} \mathrm{kg}^{-1}$, and $100 \mathrm{mg} \mathrm{K} \mathrm{kg}^{-1}$ as $\mathrm{KH}_{2} \mathrm{PO}_{4}$. Zinc was added as $\mathrm{ZnSO}_{4}$ solution. Zinc treatments were $0,100,200,500,1000$, and $2000 \mathrm{mg} \mathrm{kg}^{-1}$ vermiculite. Water was supplied to the pots everyday to maintain the moisture content of vermiculite about $1.5 \mathrm{~g} \mathrm{~g}^{-1}$ (water/vermiculite). Each treatment was brought to two $\mathrm{pH}$ levels of 6.00 and 6.50 by using $0.1 \mathrm{~N}$ $\mathrm{HCl}$ and $0.1 \mathrm{~N} \mathrm{NaOH}$, because the plant could not grow on low $\mathrm{pH}(<5.5)$ condition and almost all of zinc in vermiculite would be insoluble at high $\mathrm{pH}$ value $(>7.0)$. The plants were grown for three months inside the greenhouse, in which the temperature was maintained at $25^{\circ} \mathrm{C}$ in the daytime and $20^{\circ} \mathrm{C}$ at night, and the relative humidity was set at $70 \%$. To investigate the changes of $\mathrm{pH}$ values inside and outside rhizosphere, cylindrical rhizobags ( $12 \mathrm{~cm}$ in height and $8 \mathrm{~cm}$ in diameter) made of polyester were used to separate the vermiculite as inside and outside rhizosphere parts. The rhizobags were placed in the center of the pots, seedlings of $T$. caerulescens were planted inside the rhizobags. Water and solutes can pass through the rhizobag while the root of the plant can only grow inside 
the rhozobag.

\section{Measurement of zinc concentration}

Zinc contents of plant and vermiculite samples were determined using a fluorescent X-ray (FXR) analyzer (EDX-800, Shimadzu) at the Center of Advanced Instrumental Analysis, Kyushu University (Japan).

\section{Test of zinc accumulation in plants}

After the plant harvesting, shoots and roots were separated, washed and dried at $80^{\circ} \mathrm{C}$ for 24 hours. Dried plant materials were ground using a ball mill and zinc concentrations were determined.

\section{Analysis of vermiculite samples}

Drying and sieving vermiculite samples may change the number of exchange sites in contact with the extracting solution, and properties of the investigated vermiculite may therefore not be in agreement with the vermiculite in pots (Grimshaw, 1989). Hence, moist sub-samples of vermiculite from the pots were collected for the experiments below, but the data were corrected for dry weight (oven-dried at $105^{\circ} \mathrm{C}$ for 24 hours).

\section{Adsorption isotherms determination}

Adsorption isotherms were determined by equilibrating initial pot vermiculite samples with deionized water at a vermiculite/water ratio of 1:8 $\left(\mathrm{g} \mathrm{mL}^{-1}\right)$ in $50-\mathrm{mL}$ centrifuge tubes. Samples were equilibrated for 24 hours at room temperature. Onehour shaking ( 110 oscillations per min) on a horizontal shaker was carried out every 6 hours. Samples were centrifuged and filtered after equilibration. Zinc concentrations in the filtrate were analyzed. The difference between the initial zinc concentration and the equilibrium concentration was used to calculate the adsorbed zinc of vermiculite.

Measurements of water-soluble zinc concentrations and $p H$ values of vermiculite

Before and after the growth of plants, vermiculite samples inside and outside rhizobags were collected respectively. The extractions of water-soluble zinc in vermiculite was extracted and shaken by the same procedure mentioned above. After the $\mathrm{pH}$ values in the vermiculite-water suspension were measured with a $\mathrm{pH}$ meter (HM 16-S), the suspension water was centrifuged and filtered. Zinc concentrations of filtrate were determined, and water-soluble zinc concentrations in vermiculite were calculated.

\section{Determination of bioavailable (exchangeable + water-soluble) zinc}

Vermiculite samples inside and outside rhizobags were collected respectively before and after the growth of plants. Bioavailable zinc was extracted using $\mathrm{CaCl}_{2}(0.01 \mathrm{M})$ solution. The vermiculite/solution ratio was $1: 8\left(\mathrm{~g} \mathrm{~mL}^{-1}\right)$. The vermiculite samples and $\mathrm{CaCl}_{2}(0.01 \mathrm{M})$ solution were mixed in $50-\mathrm{mL}$ centrifuge tubes. Samples were shaken, centrifuged and filtered as mentioned above. The filtrate zinc concentrations were measured, and bioavailable zinc concentrations of vermiculite samples were calculated. 


\section{RESULTS}

\section{Adsorption isotherms}

Figure 1 shows the relationship between the different quantities of zinc adsorbed per unit mass of vermiculite and the equilibrium concentrations of solution zinc.

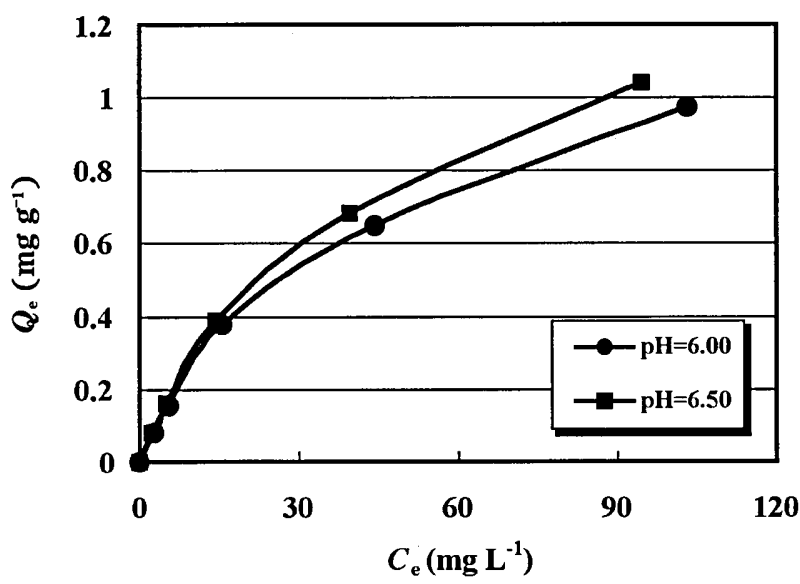

Fig. 1. Adsorption isotherms of zinc on vermiculite.

The Langmuir adsorption isotherm is represented by the following equation:

$$
\frac{C_{\mathrm{e}}}{Q_{\mathrm{e}}}=\frac{1}{K_{\mathrm{l}} d}+\frac{C_{\mathrm{e}}}{d}
$$

where $C_{\mathrm{e}}$ is the equilibrium zinc concentration in vermiculite $\left(\mathrm{mg} \mathrm{L}^{-1}\right), Q_{\mathrm{e}}$ is the amount of zinc adsorbed by vermiculite at equilibrium time $\left(\mathrm{mg} \mathrm{g}^{-1}\right), d$ and $K_{1}$ are Langmuir constants related to the adsorption capacity and energy of adsorption, respectively. The plots of $C_{\mathrm{e}} / Q_{\mathrm{e}}$ versus $C_{\mathrm{e}}$ are linear, showing that zinc adsorption conforms to Langmuir model (Fig. 2).

The Freundlich adsorption isotherm is represented by the following equation:

$$
\log Q_{\mathrm{e}}=\log K_{\mathrm{f}}+n \log C_{\mathrm{e}}
$$

where $Q_{\mathrm{e}}$ is the amount of zinc adsorbed by vermiculite at equilibrium time ( $\left.\mathrm{mg} \mathrm{g}^{-1}\right), C_{\mathrm{e}}$ is the equilibrium zinc concentration in vermiculite $\left(\mathrm{mg} \mathrm{L}^{-1}\right)$, and $K_{\mathrm{f}}$ and $n$ are Freundlich constants. Linear plots of $\log Q_{\mathrm{e}}$ versus $\log C_{\mathrm{e}}$ show that zinc adsorption by vermiculite also follows Freundlich model (Fig. 3). Values of Langmuir and Freundlich constants are shown in Table 1.

\section{Zinc uptake in Thlaspi caerulescens}

In this experiment, the maximum zinc concentration accumulated in the shoot of $T$. caerulescens was $23.69 \mathrm{mg} \mathrm{g}^{-1}$ (dry weight). For each treatment, zinc concentration of 


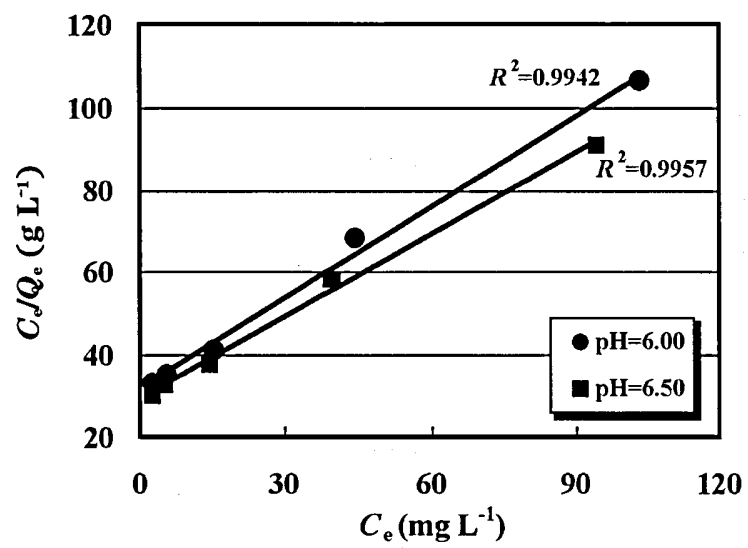

Fig. 2. Langmuir isotherms for zinc adsorption by vermiculite.

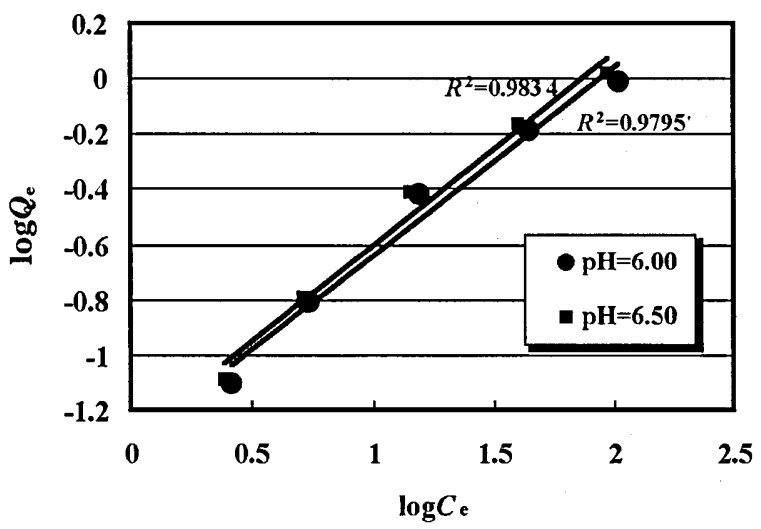

Fig. 3. Freundlich isotherms for zinc adsorption by vermiculite.

Table 1. Langmuir and Freundlich constants for zinc adsorption.

\begin{tabular}{cccccccc}
\hline \multirow{2}{*}{$\mathrm{pH}$} & \multicolumn{3}{c}{$\begin{array}{c}\text { Langmuir } \\
\text { Adsorption }\end{array}$} & & \multicolumn{3}{c}{$\begin{array}{c}\text { Freundlich } \\
\text { Adsorption }\end{array}$} \\
\cline { 2 - 4 } \cline { 6 - 8 } & $K_{\mathrm{I}}$ & $d$ & $R^{2}$ & & $K_{\mathrm{f}}$ & $n$ & $R^{2}$ \\
\hline 6.00 & 0.023 & 1.36 & 0.9943 & & 0.047 & 0.68 & 0.9795 \\
6.50 & 0.022 & 1.52 & 0.9957 & & 0.049 & 0.70 & 0.9834 \\
\hline
\end{tabular}

the plant shoot was higher at $\mathrm{pH} 6.00$ than that at $\mathrm{pH} 6.50$. But the differences were not significantly large (Fig. 4). 


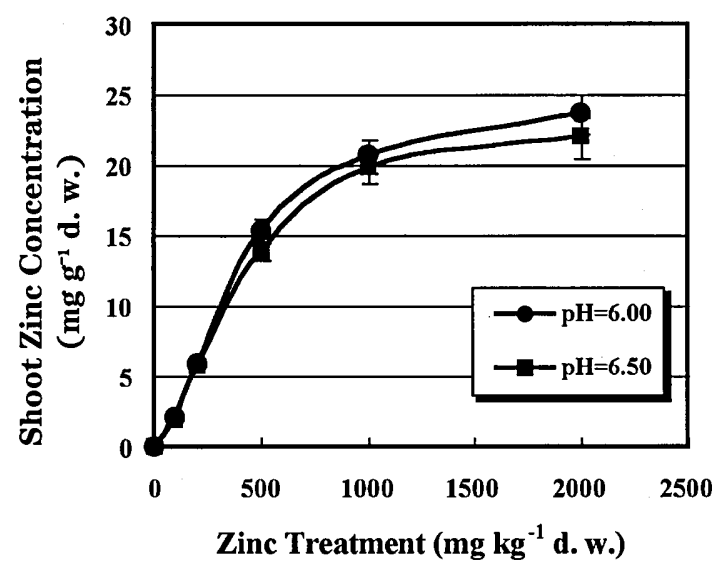

Fig. 4. Concentrations of zinc accumulated in the shoots of Thlaspi caerulescens.

In this paper, the difference between $\mathrm{CaCl}_{2}$-extractable and water-extractable zinc was regarded as exchangeable zinc, and non-exchangeable zinc was obtained from the difference between zinc added to vermiculite and $\mathrm{CaCl}_{2}$-extractable zinc. Raising initial zinc concentrations in vermiculite resulted in the increase in zinc accumulation in shoots of $T$. caerulescens. However, zinc accumulated in shoots of $T$. caerulescens indicated high linear-correlation with zinc in exchangeable fraction compared with that in other fractions of vermiculite. The relationships between shoot zinc concentrations of $T$. caerulescens and the initial zinc concentrations in different fractions of vermiculite are shown in Figure 5. The values of coefficient of determination $R^{2}$ are presented in Table 2.

\section{Changes of $\mathrm{pH}$ values in vermiculite}

Table 3 shows that $\mathrm{pH}$ values of vermiculite did not differ significantly between inside and outside rhizobags after the growth of plants. This results conformed with McGrath et al. (1997) and Knight et al. (1997), suggesting that the rhizosphere acidification was not the main mechanism for zinc uptake by $T$. caerulescens.

\section{Comparison between zinc uptake by plants and the loss of zinc in vermiculite}

The average decrease in zinc for different fractions of vermiculite and the average amount of zinc accumulated by T. caerulescens of each treatment are shown in Figure 6. For each treatment, the amount of zinc accumulated by the plant in each pot is larger than the decrease in $\mathrm{CaCl}_{2}$-extractable zinc. This means that zinc accumulated by $T$. careulescens is not only from water-soluble and exchangeable fractions, but also from non-exchangeable pool. The further calculation revealed that $67.06-82.27 \%$ of the total zinc uptake by $T$. careulescens was contributed by $\mathrm{CaCl}_{2}$-extrctable zinc, and the remaining $17.73-32.94 \%$ was from non-exchangeable fraction. With the enhancement of zinc concentration in vermiculite, the contribution of water-extractable zinc to the total plant uptake rose from $24.62-41.41 \%$ while the contribution of exchangeable zinc decreased 


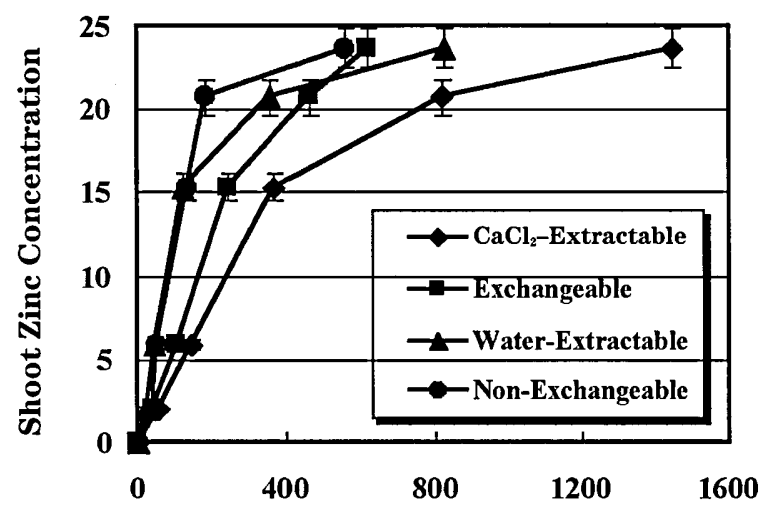

Zinc Concentration in Vermiculite (mg kg-1 d. w.)

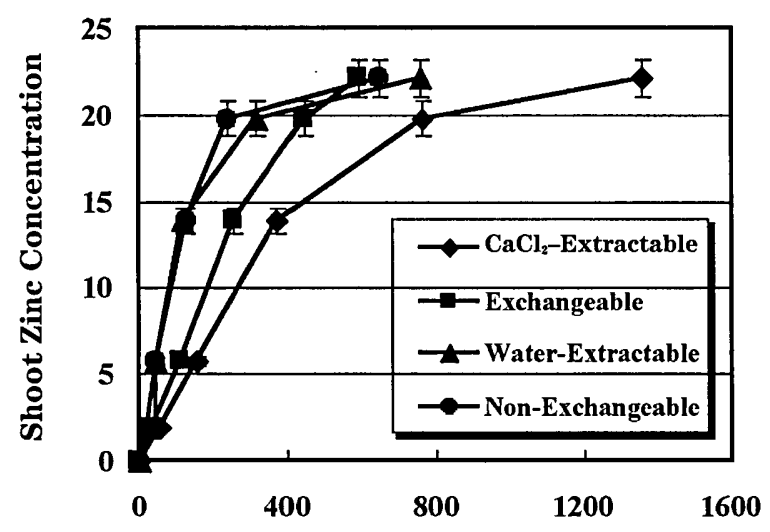

Zinc Concentration in Vermiculite $\left(\mathrm{mg} \mathrm{kg} \mathbf{~ d}^{-1} \mathbf{~ w . )}\right.$

Fig. 5. Relationships between zinc accumulated in the shoots of Thlaspi caerulescens and different initial zinc fractions in vermiculite. (A): $\mathrm{pH}=6.00$. (B): $\mathrm{pH}=6.50$.

Table 2. Values of coefficient of determination $R^{2}$ for linear-correlation between zinc in shoot and vermiculite.

\begin{tabular}{ccc}
\hline Fraction & $\mathrm{pH}=6.00$ & $\mathrm{pH}=6.50$ \\
\hline $\mathrm{CaCl}_{2}-$ Extractable & 0.8437 & 0.8540 \\
Exchangeable & 0.9483 & 0.9616 \\
Water-Extractable & 0.7253 & 0.7242 \\
Non-Exchangeable & 0.6836 & 0.7002 \\
\hline
\end{tabular}


Table 3. $\mathrm{pH}$ values of vermiculite after the growth of plants.

\begin{tabular}{|c|c|c|c|c|}
\hline \multirow{3}{*}{$\begin{array}{l}\text { Treatment } \\
\left(\mathrm{mg} \mathrm{kg}^{-1}\right)\end{array}$} & \multicolumn{4}{|c|}{ Final pH Values } \\
\hline & \multicolumn{2}{|c|}{ Initial $\mathrm{pH}=6.00$} & \multicolumn{2}{|c|}{ Initial $\mathrm{pH}=6.50$} \\
\hline & $\begin{array}{c}\text { Inside } \\
\text { Rhizobag }\end{array}$ & $\begin{array}{c}\text { Outside } \\
\text { Rhizobag }\end{array}$ & $\begin{array}{c}\text { Inside } \\
\text { Rhizobag }\end{array}$ & $\begin{array}{l}\text { Outside } \\
\text { Rhizobag }\end{array}$ \\
\hline 0 & 6.03 & 6.01 & 6.54 & 6.51 \\
\hline 100 & 6.06 & 6.01 & 6.54 & 6.50 \\
\hline 200 & 6.05 & 6.02 & 6.57 & 6.51 \\
\hline 500 & 6.08 & 6.00 & 6.52 & 6.50 \\
\hline 1000 & 6.05 & 6.02 & 6.53 & 6.51 \\
\hline 2000 & 6.04 & 6.00 & 6.54 & 6.50 \\
\hline
\end{tabular}

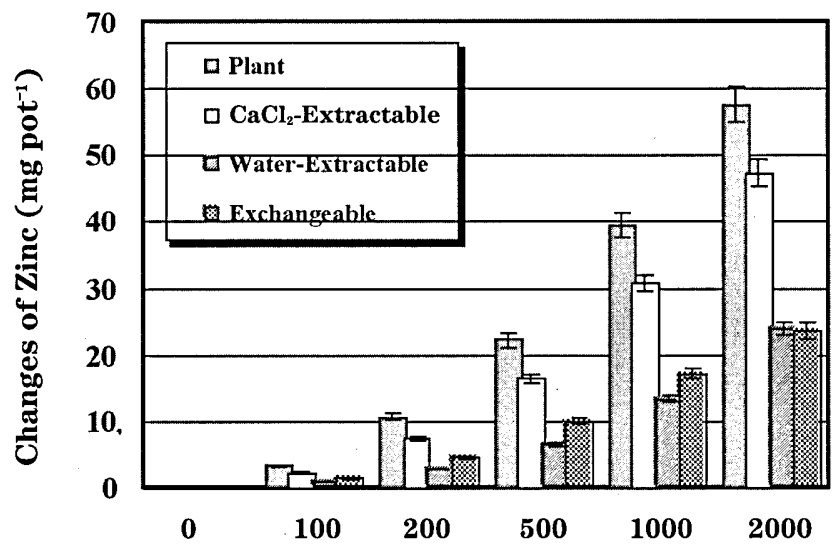

\section{Zinc Treatment}

( $\mathrm{mg} \mathrm{kg}^{-1}$ d. w.)

Fig. 6. Comparison between zinc accumulated by Thlaspi caerulescens and the decrease of zinc in vermiculite.

from $42.44-40.86 \%$.

\section{DISCUSSION}

As a hyperaccumulator, $T$. caerulescens accumulated large quantity of zinc in its above-ground biomass after the growth in high zinc concentration vermiculite (Fig. 4). This can be considered to be resulted from its genetic advantages, which have been investigated by many researchers (Pence et al., 2000; Assunção et al., 2001).

Generally, when water-soluble zinc cations from $\mathrm{ZnSO}_{4}$ are added to vermiculite, they 
can migrate from the water-soluble fraction to exchangeable and non-exchangeable fractions. A zinc dynamic equilibrium will occur among different fractions. The $\mathrm{pH}$ value is widely acknowledged to be the principal factor governing the plant availability because of its influence on zinc solubility and adsorption (Singh and Abrol, 1985). However, in this research, the results of shoot zinc uptake by T. caerulescens obtained at $\mathrm{pH} 6.00$ and pH6.50 did not show significant pH dependence (Fig. 4). One of the reasons may be that the zinc concentration in vermiculite does not change with $\mathrm{pH}$ due to high permanent charge on vermiculite surface. In addition, $\mathrm{ZnSO}_{4}$ added to the soil can be completely dissolved at both $\mathrm{pH} 6.00$ and $\mathrm{pH} 6.50$, and by comparison, the concentrations of less-soluble zinc species such as zinc carbonate and hydroxide are very low in this experiment. Therefore, the adsorption equilibrium and zinc distribution for different fractions were predominantly controlled by concentrations of zinc added to vermiculite (Fig. 1, Fig. 2, and Fig. 3). This leads to a concentration dependent result rather than a $\mathrm{pH}$ dependent one.

Although increasing the amount of zinc added to vermiculite enhanced the shoot zinc uptake by $T$. caerulescens, the linear correlations between shoot zinc content and the initial zinc concentrations of various fractions in vermiculite are quite different (Fig. 5 and Table 2). Generally, the growing roots of plants are thought to be exposed to the solution phase. The zinc concentration in the solution phase seems to be a predominant soil condition affecting zinc uptake by plant roots. However, the high rate of zinc uptake into roots of $T$. caerulescens results in very high demands for zinc at the root surface. This may cause the zinc depletion in the solution near the root surface. The mass flow can only contribute a small amount of zinc to the root even at relatively high soil concentrations (Whiting et al., 2003). Hence, a concentration gradient will develop and diffusion will occur. On the other hand, zinc uptake by plant disturbs the equilibrium of zinc between solution phase and solid phase near the zone of zinc depletion. The soluble zinc will be replenished by exchangeable pool as the plant removes it. Thus, the supply of zinc to the root surface conforms to a circulation process involving zinc adsorption, desorption, and resorption to the medium. As zinc movement from nonexchangeable fraction to exchangeable pool is much more difficult than zinc releasing to water-soluble fraction from exchangeable pool, exchangeable pool could play a key role in the zinc supply in vermiculite. Therefore, a high linear-correlation existed between the shoot zinc of $T$. caerulescens and the initial exchangeable zinc (Fig. 5 and Table 2). In the further investigation, it was discovered that more than $40 \%$ of the zinc accumulated by $T$. caerulescens was contributed by exchangeable zinc. Only for initial zinc concentration of $2000 \mathrm{mg} \mathrm{kg}^{-1}$, zinc supplied by water-soluble pool accounted for more than $40 \%$ of the total zinc accumulated by the plant (Fig. 6). Apparently, exchangeable zinc predominantly influenced the zinc uptake by plants, especially when zinc concentration in vermiculite is relatively lower.

Some authors (Knight et al., 1997; McGrath et al., 1997) reported that $T$. caerulescens had remarkable ability to mobilize zinc in non-labile fraction of the soil, which contributed more than $90 \%$ of the total zinc uptake by plants. Such strong zinc mobilizing results were not obtained in our experiment, but still there are $17.73-32.94 \%$ of the total zinc uptake by the plants can be considered from non-exchangeable fraction. The lower the zinc concentration, the more the zinc acquired by the plant from 
non-exchangeable fraction. The explanation is that, in the case of high zinc concentration, plant roots are easy to uptake more zinc from soil solution and exchangeable pool. In agreement with the authors above, by determining the $\mathrm{pH}$ changes in vermiculite before and after the growth of $T$. caerulescens (Table 3), we concluded that the acidification of solution phase could not be the method by which $T$. caerulescens increase zinc availability. In other words, the acquirement of extremely insoluble zinc from vermiculite by $T$. caerulescens was not due to the acidification. Small amount of zinc may reverse from non-exchangeable fraction to exchangeable part in the dynamic equilibrium of zinc in vermiculite. But the rate of this process is very slow. Moreover, it is impossible to supply large amount of available zinc to the plant. Thus, an active zinc-mobilizing mechanism by $T$. caerulescens may exist, especially when the concentrations of water-soluble and exchangeable zinc are relatively lower. It has been proved by Schwartz et al. (1999) that the root growth of $T$. caerulescens responded positively to zinc in soil. The roots of $T$. caerulescens exhibited high affinity for patches containing zinc with high concentrations. As the root of $T$. caerulescens cannot dissolve zinc by the acidification or secrete specific zinc-mobilizing compounds (Zhao et al., 2001), the solid phase-root-uptake may be a possible way for $T$. caerulescens to mobilize zinc, which can be explained by the contact exchange theory (Jenny and Overstreet, 1939). If the solid phase-root-uptake was one of the mechanisms involved in zinc mobilization, it would also support the predominant effect of exchangeable pool on zinc uptake by $T$. caerulescens. However, the contact exchange theory has not been established as an essential mechanism. Therefore, it is necessary to confirm that in what case the solid phase-root-uptake will occur. And surface characteristics of the plant root and the solid phase must be seriously investigated. Moreover, mechanisms of interactions between zinc and the plant root surface and the movement of zinc in the solid phase should be well understood.

\section{REFERENCES}

Assunção, A. G. L., P. De Costa Martins, S. De Folter, R. Vooijs, H. Schat and M. G. M. Aarts 2001 Elevated expression of metal transporter gene in three accessions of the metal hyperaccumulator Thlaspi caerulescens. Plant Cell Environ., 24: 217-226

Brown, S. L., R. L. Chaney, J. S. Angle and A. J. Baker 1994 Phytoremediation potential of Thlaspi caerulescens and bladder campion for zinc- and cadmium-contaminated soil. J. Environ. Qual., 23: $1151-1157$

Ebbs, S. D., M. M. Lasat, D. J. Brady, J. Cornish, R. Gordon and L. V. Kochian 1997 Phytoextraction of cadmium and zinc from a contaminated soil. J. Environ. Qual., 26: 1424-1430

Grimshaw, H. M. 1989 Analysis of soils. In "Chemical Analysis of Ecological Materials", ed. by S. E. Allen, Blackwell Scientific Publications, Oxford, pp. 7-45

Iyengar, S. S., D. C. Martens and W. P. Miller 1981 Distribution and plant availability of soil zinc fractions. Soil Sci. Soc. Am. J., 45: 735-739

Jenny, H. and R. Overstreet 1939 Cation interchange between plant roots and soil colloids. Soil Sci., 47: $257-272$

Knight, B., F. J. Zhao, S. P. McGrath and Z. G. Shen 1997 Zinc and cadmium uptake by the hyperaccumulator Thlaspi caerulescens in contaminated soils and its effects on the concentration and chemical speciation of metals in soil solution. Plant Soil, 197: 71-78

McGrath, S. P., Z. G. Shen and F. J, Zhao 1997 Heavy metal uptake and chemical changes in the rhizosphere of Thlaspi caerulenscens and Thlaspi ochroleucum grown in contaminated soils. Plant Soil, 188: 153-159

Pence, N. S., P. B. Larsen, S. D. Ebbs, D. L. D. Letham, M. M. Lasat, D. F. Garvin, D. Eide and L. V. Kochian 
2000 The molecular physiology of heavy metal transport in the Zn/Cd hyperaccumulator Thlaspi caerulescens. Proc. Natl. Acad. Sci. USA, 97: 4956-4960

Reeves, R. D. and A. J. M. Baker 2000 Metal-accumulating plants. In "Phytoremediation of Toxic Metals - Using Plants to Clean Up the Environment", ed. by I. Raskin and B. D. Ensley, John Wiley \& Sons, Inc., New York, pp. 193-229

Schwartz, C., J. L. More, S. Saumier, S. N. Whiting and A. J. M. Baker 1999 Root development of the zinc-hyperaccumulator plant Thlaspi caerulescens as affected by metal origin, content and localization in soil. Plant soil, 208: 103-115

Singh, M. V. and I. P. Abrol 1985 Solubility and adsorption of zinc in a sodic soil. Soil Sci., 140: 406-411

Whiting, S. N., M. R. Broadley and P. J. White 2003 Applying a solute transfer model to phytoextraction: Zinc acquisition by Thlaspi caerulescens. Plant Soil, 249: 45-56

Wild, A. and J. Keay 1964 Cation-exchange equilibria with vermiculite. J. Soil Sci., 15: 135-144

Zhao, F. J., R. E. Hamon and M. J. McLaughlin 2001 Root exudates of the hyperaccumulator Thlaspi caerulescens do not enhance metal mobilization. New Phytol., 151: 613-620

Zhu, B. and A. K. Alva 1993 Distribution of trace metals in some sandy soils under citrus production. Soil Sci. Soc. Am. J., 57: 350-355 